\title{
Organic acids, sugars, vitamin C content and some pomological characteristics of eleven hawthorn species (Crataegus spp.) from Turkey
}

\author{
Muttalip Gundogdu', Koray Ozrenk², Sezai Ercisli ${ }^{3}$, Tuncay Kan ${ }^{4}$, Ossama Kodad ${ }^{5^{*}}$ and Attila Hegedus ${ }^{6}$
}

\begin{abstract}
Background: The Hawthorn (Crateagus sp.) mostly occurs around the temperate region of the world with a high number of species, producing a fruit with numerous beneficial effects for human health. The aim of the study was to determine organic acid and sugar contents in the fruit of a number of hawthorn species grown in Erzincan province of Turkey.

Results: Citric acid was the predominant organic acid in all hawthorn species and C. pseudoheterophylla had the highest citric acid content $(23.688 \mathrm{~g} / 100 \mathrm{~g})$. There were not statistically significant differences among hawthorn species (except C. atrosanguinea Pojark) in terms of fumaric acid content. C.pontica C.Koch had a higher content of vitamin C (9.418 mg/100 g) compared to other species. Fructose was the predominant sugar component in all species and C. monogyna subsp. monogyna Joiq had the highest fructose content (18.378 g/100 g).

Conclusions: The high fruit quality of the studied species indicates the importance of this fruit in human nutrition as a natural source. The study revealed that there were differences in terms of fruit characteristics among hawthorn species and thus better quality hawthorn genotypes can be selected within the species. Hence, this study is considered to be a valuable reference for forthcoming studies. The high fruit quality of the studied species indicates the importance of this fruit in human nutrition as a natural source.
\end{abstract}

Keywords: Crataegus, Diversity, Fruit characteristics, Organic acids

\section{Background}

There has been a keen interest to wild edible fruits including hawthorn that have not been cultivated in common orchards. Their fruits have numerous beneficial effects for human health [1]. The consequence of this neglect is that wild edible fruit species used in developing countries are poorly known. Hawthorn (Crateagus sp.) mostly occurs around the temperate region of the world with a high number of species but the main problem is recognizing species [2].

Turkey is a significant genetic center of hawthorn (Crataegus spp.) and wild growing hawthorn species has a wide distribution. Hawthorn species are members of the family Rosaceae, subfamily Maloideae, tribe Crataegeae and genus Crataegus. Turkey is one of the motherlands of

\footnotetext{
* Correspondence: osama.kodad@yahoo.es

${ }^{5}$ Departement of Pomology, National School of Agriculture, Meknes, Morocco

Full list of author information is available at the end of the article
}

the species that is widely distributed in North Europe, temperate regions of Asia, Africa and North America [2]. There are 165-200 hawthorn species worldwide and about 17 hawthorn species can be found in Turkey [2]. Diverse Crataegus species grow in different regions of the world [3]. Such worldwide rich species diversity is attributed to birds and other animals and they disperse its seeds. Hawthorns are deciduous and thorny trees or bushes which have plentiful and conspicuous flowers in bunches in spring; have yellowish, orange or reddish fruits in autumn; have lobbed leaves which also turn similar colors as fruits in fall $[4,5]$.

Organic acid contents of fruits vary according to species. In particular, sugar-acid balance and contents are the primary determinants of taste attributes of fruit. Organic acids in fruits and vegetables mostly form compounds such as salt, ester and glycoside [6]. Since the acids in fruits are immediately oxidized, they do not have harmful effects on the body. As their salts are 
alkaline forming elements, they are highly important in human nutrition [6]. Due to their beneficial effects in preventing cardiovascular diseases, hawthorn species have recently become important in nutrition and nutraceuticals [7]. Fruit acids that enable digestion of nutrients and stimulate blood circulation are among the quality parameters for hawthorn fruits.

Hawthorn fruits and leaves have abundant content of flavonoids and procyanidins which have antioxidant, free radical scavenging, anti-inflammatory, vasorelaxing and hypolipidemic properties [8-11]. Flowers and fruits are used in pharmaceutics for medicinal purposes. They help to lower blood tension and strengthen the heart. Hawthorn berries contain glycosides which boost heart health. They are used to treat heart beat irregularities due to aging or neural disorders. They are also good for atherosclerosis, insomnia, seasonal mood swings and nervous system disorders. The herb is non-poisonous and can be used safely for long-term treatments [12]. The berries have laxative and diuretic properties [13]. They contain triterpene acids, choline, acetylcholine, trimethylamine, caffeic and ascorbic acids, aminoacids, adenine and adenosine [12]. Vitamins B1, B2, B6 and C as well as 17 aminoacids (about 3.1\%) are determined in hawthorn berries [3].

Recent studies have demonstrated the important role of hawthorn fruits in human health and nutrition. Accordingly, hawthorn fruits are becoming more popular and their consumption has been increasing recently. The hawthorn species used in this study are abundantly grown in Turkey. The study aimed to determine organic acid, sugar, vitamin $\mathrm{C}$ content and some pomological characteristics of 11 wild hawthorn species grown in Erzincan region, Turkey. These parameters are important for the determination of quality of hawthorn fruits. The study is important for exploring organic acid and sugar contents in hawthorn species on which only limited literature is available.

\section{Results and discussions}

There were statistically significant differences among species in terms of morphological (fruit weight, fruit dimensions, seed number, seed weight, fruit stalk length and width) and biochemical (SSC, soluble solid content, $\mathrm{pH}$, acidity (Table 1). C. pseudoheterophylla Pojark. had the highest fruit weight $(3.48 \mathrm{~g})$. In terms of SSC, $C$. monogyna subsp. azarella Jocq. had the highest SSC content (20.00\%) while C. szovitsii Pojark. had the lowest amount $(2.35 \%)$ (Table 1$)$. The highest acidity levels were identified respectively in C. monogyna subsp.azarella Jocq. (5.99\%) and C. aroni var. aroni (L) Bosc.ex DC. $(2.40 \%)$ (Table 1$)$. The fruit weights of hawthorn genotypes were reported previously between 0.81-2.14 g [13]. In some Crataegus (Chinese hawthorn) genotypes, the fruit length was reported to be range between 1.50$2.90 \mathrm{~mm}$, the fruit width between $1.60-3.60 \mathrm{~mm}$ and the fruit weights between 3.4-16 g [3]. In the literature, the acidity levels of $C$. pinnatifida and $C$. altaica were given as $1.5-4.5 \%$ and $0.56 \%$, respectively [14]. Research has demonstrated that morphological and biochemical characteristics of fruits are affected by genetic factors, climatic factors, climate and soil structure. While some findings of this study are in agreement with those of other researchers, some findings are in discord. This is attributed to the variability of hawthorn species used in the studies as well as other environmental factors.

Organic acids are known to affect particularly taste formation and many physiological processes. Oxalic acid,

Table 1 Pomological characteristics and Soluble Solid Content (SSC), pH and acidity of hawthorn species (fresh weight basis)

\begin{tabular}{|c|c|c|c|c|c|c|c|c|c|c|}
\hline Species & $\begin{array}{c}\text { Fruit } \\
\text { weight (g) }\end{array}$ & $\begin{array}{c}\text { Fruit } \\
\text { height }(\mathrm{mm})\end{array}$ & $\begin{array}{l}\text { Fruit width } \\
\qquad(\mathrm{mm})\end{array}$ & $\begin{array}{c}\text { Seed } \\
\text { number }\end{array}$ & $\begin{array}{c}\text { Seed } \\
\text { weight }(g)\end{array}$ & $\begin{array}{c}\text { Fruit stalk } \\
\text { length }(\mathrm{mm})\end{array}$ & $\begin{array}{l}\text { Fruit stalk } \\
\text { thickness } \\
(\mathrm{mm})\end{array}$ & SCC (\%) & $\mathrm{pH}$ & $\begin{array}{c}\text { Acidity } \\
(\%)\end{array}$ \\
\hline C.pontica & $2.29 c^{*}$ & $13.13 \mathrm{bcd}$ & $12.15 \mathrm{C}$ & $1.00 \mathrm{e}$ & $0.24 \mathrm{f}$ & $7.21 \mathrm{~b}$ & 0.87 cde & $17.51 \mathrm{~b}$ & $4.58 \mathrm{~b}$ & $0.88 \mathrm{C}$ \\
\hline C. atrosanguinea. & $1.49 \mathrm{~d}$ & $13.51 \mathrm{bc}$ & $13.36 \mathrm{c}$ & $4.00 \mathrm{~b}$ & $0.45 \mathrm{de}$ & $0.83 d$ & 0.89 b-e & $11.61 \mathrm{c}$ & $4.29 \mathrm{~b}$ & $1.65 \mathrm{~b}$ \\
\hline C. meyeri & $0.58 \mathrm{e}$ & 10.86 e & $10.38 d$ & $1.00 \mathrm{e}$ & $0.13 \mathrm{~g}$ & $13.60 \mathrm{a}$ & 0.36 de & $3.05 \mathrm{e}$ & $5.06 \mathrm{ab}$ & $0.22 \mathrm{f}$ \\
\hline C. pseudoheterophylla & $3.48 \mathrm{a}$ & $1.67 f$ & $2.21 \mathrm{e}$ & $4.00 \mathrm{~b}$ & $0.68 \mathrm{ab}$ & $1.71 \mathrm{~d}$ & 0.10 e & $7.75 \mathrm{~d}$ & $4.22 \mathrm{~b}$ & $0.46 \mathrm{e}$ \\
\hline C. orientalis var. orientalis & $3.20 \mathrm{ab}$ & $15.56 \mathrm{a}$ & $17.68 \mathrm{a}$ & $4.00 \mathrm{~b}$ & $0.75 a$ & $4.14 \mathrm{C}$ & $1.63 \mathrm{ab}$ & $11.85 \mathrm{C}$ & $4.26 \mathrm{~b}$ & $1.78 \mathrm{~b}$ \\
\hline $\begin{array}{l}\text { C. monogyna subsp. } \\
\text { azarella }\end{array}$ & $2.93 \mathrm{~b}$ & $14.75 \mathrm{ab}$ & $14.80 \mathrm{~b}$ & $2.00 \mathrm{~d}$ & $0.54 \mathrm{~cd}$ & $1.57 \mathrm{~d}$ & $1.90 \mathrm{a}$ & $20.00 \mathrm{a}$ & 5.99 a & $0.41 \mathrm{e}$ \\
\hline $\begin{array}{l}\text { C. monogyna subsp. } \\
\text { monogyna }\end{array}$ & $1.35 d$ & $13.12 \mathrm{bcd}$ & $12.55 \mathrm{C}$ & $1.00 \mathrm{e}$ & $0.29 \mathrm{f}$ & $7.63 \mathrm{~b}$ & 0.82 cde & $18.25 b$ & $4.73 \mathrm{ab}$ & $0.82 \mathrm{c}$ \\
\hline C. curvisepala & 0.62 e & 11.20 de & $10.02 \mathrm{~d}$ & $1.00 \mathrm{e}$ & $0.26 \mathrm{f}$ & $13.32 \mathrm{a}$ & 0.67 cde & $3.35 \mathrm{e}$ & $5.22 \mathrm{ab}$ & $0.65 d$ \\
\hline C. szovitsii & $1.25 \mathrm{~d}$ & 12.54 cde & $12.69 \mathrm{c}$ & $3.00 \mathrm{c}$ & $0.27 \mathrm{f}$ & $8.14 \mathrm{~b}$ & $1.37 \mathrm{abc}$ & $2.35 \mathrm{e}$ & $4.50 \mathrm{~b}$ & $0.31 \mathrm{ef}$ \\
\hline Crataegus pentagyna & $1.60 \mathrm{~d}$ & $1.29 \mathrm{f}$ & $1.44 \mathrm{e}$ & 5.005 & $0.61 b c$ & $1.58 d$ & $0.20 \mathrm{e}$ & $12.02 \mathrm{C}$ & $4.36 \mathrm{~b}$ & $0.45 \mathrm{e}$ \\
\hline C. aroni var. aroni & $3.00 \mathrm{~b}$ & $15.72 \mathrm{a}$ & $17.67 \mathrm{a}$ & $4.00 \mathrm{~b}$ & $0.43 \mathrm{e}$ & $7.18 \mathrm{~b}$ & $1.05 \mathrm{bcd}$ & $11.50 \mathrm{c}$ & $4.61 \mathrm{~b}$ & $2.40 \mathrm{a}$ \\
\hline
\end{tabular}

*There were significant $(\mathrm{P}<0.01)$ differences among the different letters in the same columns. 
citric acid, tartaric acid, succinic acid, fumaric acid and malic acid contents in fruits of 11 hawthorn fruit species were examined in this study (Table 2).

There were statistically significant differences among species in terms of organic acid contents (except fumaric acid) $(\mathrm{p}<0.05)$. C. pseudoheterophylla Pojark. had the highest citric acid content $(23.688 \mathrm{~g} / 100 \mathrm{~g})$ while C. monogyna subsp. monogyna Joiq. had the lowest (1.953 g/100 g) citric acid content. The highest malic acid content was measured in C. pseudoheterophlla Pojark. (2.671 g/100 g) and the lowest malic acid content was determined in $C$. pontica C.Koch. (1.045 g/100 g) (Table 2). C. atrosanguinea Pojark. had the highest oxalic acid content (12.419 g/ $100 \mathrm{~g}$ ). Liu et al. [11] conducted a study on C. pinnatifida var. major fruits grown in China and reported malic acid content as $0.72 \mathrm{~g} / 100 \mathrm{~g}$ and quinic acid content as $1.87 \mathrm{~g} /$ $100 \mathrm{~g}$. The same researchers also studied on C. brettschneideri hawthorn species and identified malic acid content as $0.68 \mathrm{~g} / 100 \mathrm{~g}$, citric acid content as $4.56 \mathrm{~g} / 100 \mathrm{~g}$ and quinic acid content as $0.61 \mathrm{~g} / 100 \mathrm{~g}$. In another study, tartaric acid and succinic acid contents were explored in the hawthorn species of $C$. pinnatifida var. major, $C$. scabrifolia, C. kansuensis, C. hupehensis, and C. cuneata [15]. While some of the values determined in this study were close to the values reported in other studies, some values were found to be higher and some were found to be lower. These variations can be attributed to different genetic characteristics of study materials as well as climatic conditions and other environmental factors.

The glucose, fructose, saccharose and vitamin $C$ contents of hawthorn species were also investigated. There were statistically significant differences among species in terms of sugar and vitamin $\mathrm{C}$ contents $(\mathrm{p}<0.05)$ (Table 3). C. monogyna subsp. monogyna Joiq. had the highest glucose $(13.893 \mathrm{~g} / 100 \mathrm{~g})$ and fructose $(18.378 \mathrm{~g} / 100 \mathrm{~g})$ contents. The lowest glucose content $(6.672 \mathrm{~g} / 100 \mathrm{~g})$ was determined in C. szovitsii Pojark and the lowest fructose content
(8.527 g/100 g) was detected in C.pontica C.Koch. Crataegus pentagyna and C. monogyna subsp. monogyna had the highest $(1.564 \mathrm{~g} / 100 \mathrm{~g})$ and lowest $(0.970 \mathrm{~g} / 100 \mathrm{~g})$ saccharose contents, respectively (Table 3 ).

In terms of vitamin $\mathrm{C}$ content, C.pontica C.Koch. had the highest $(9.418 \mathrm{mg} / 100 \mathrm{~g})$ and $C$. aroni var. aroni $(\mathrm{L})$ Bosc.ex DC. had the lowest $(1.555 \mathrm{mg} / 100 \mathrm{~g})$ contents (Table 3). Fructose contents were generally found to be higher than glucose and saccharose contents in this study. In a study on Crataegus pinnatifida var. major grown in China, fructose content was determined as $13.40 \mathrm{~g} / 100 \mathrm{~g}$, glucose content as $11.67 \mathrm{~g} / 100 \mathrm{~g}$ and saccharose content as $5.61 \mathrm{~g} / 100 \mathrm{~g}$ [11]. Peaches and apricots have almost equal amounts of glucose, fructose and saccharose. In other hard seeded fruits and berry fruits, glucose and fructose contents are more predominant. Monosaccharides are important since they produce hydroxymethylfurfural by food processing technology with the effects of temperature and acid [16].

The hawthorn species (C. szovitsii Pojark., C.pontica C. Koch., C. aroni var. aroni (L) Bosc.ex DC., C. atrosanguinea Pojark., C. meyeri Pojark., C. curvisepala Lindman, $C$. monogyna subsp. monogyna Joiq., C. pseudoheterophlla Pojark., C. orientalis var. orientalis Pallas ex Bieb., C. monogyna subsp.azarella Jocq., Crataegus pentagyna.) that are particularly widespread in the Eastern Anatolia Region of Turkey were examined in this study. In terms of organic acid distribution, citric acid content was identified to be higher than the contents of other organic acids and citric acid was found to be the predominant organic acid in all hawthorn species. Compared to the findings of Liu et al. [11], similar glucose and fructose contents were identified in this study while saccharose contents were lower. Liu et al. [11] demonstrated that while some hawthorn fruit species contained saccharose, some species lacked this compound. In this study conducted in Erzincan region, all examined hawthorn fruit species were found to

Table 2 Fruit organic acid contents of hawthorn species (g/100 $\mathrm{g}$ fresh weight basis)

\begin{tabular}{lcccccc}
\hline Species & Oxalic acid & Citric acid & Tartaric acid & Succinic acid & Fumaric acid & Malic acid \\
\hline C. pontica & $1.453 \pm 0.024 \mathrm{f}$ & $3.128 \pm 0.007 \mathrm{e}$ & $1.205 \pm 0.040 \mathrm{c}$ & $2.174 \pm 0.197 \mathrm{~b}$ & $0.155 \pm 0.001 \mathrm{~b}$ & $1.045 \pm 0.016 \mathrm{k}$ \\
C. atrosanguinea. & $12.419 \pm 0.054 \mathrm{a}$ & $19.218 \pm 0.027 \mathrm{~b}$ & $0.605 \pm 0.026 \mathrm{~d}$ & $1.082 \pm 0.148 \mathrm{i}$ & $0.235 \pm 0.025 \mathrm{a}$ & $2.246 \pm 0.038 \mathrm{c}$ \\
C. meyeri & $1.513 \pm 0.014 \mathrm{ef}$ & $2.548 \pm 0.092 \mathrm{f}$ & $1.668 \pm 0.101 \mathrm{~b}$ & $1.392 \pm 0.073 \mathrm{~g}$ & $0.019 \pm 0.000 \mathrm{~b}$ & $1.518 \pm 0.021 \mathrm{~g}$ \\
C. pseudoheterophylla & $2.461 \pm 0.036 \mathrm{~cd}$ & $23.688 \pm 0.041 \mathrm{a}$ & $2.217 \pm 0.038 \mathrm{a}$ & $2.581 \pm 0.163 \mathrm{a}$ & $0.016 \pm 0.000 \mathrm{~b}$ & $2.671 \pm 0.050 \mathrm{a}$ \\
C. orientalis var. orientalis & $2.687 \pm 0.040 \mathrm{c}$ & $2.532 \pm 0.056 \mathrm{f}$ & $1.579 \pm 0.063 \mathrm{~b}$ & $1.285 \pm 0.102 \mathrm{~h}$ & $0.009 \pm 0.000 \mathrm{~b}$ & $1.347 \pm 0.043 \mathrm{i}$ \\
C. monogyna subsp.azarella & $3.276 \pm 0.147 \mathrm{~b}$ & $5.665 \pm 0.236 \mathrm{~d}$ & $0.763 \pm 0.034 \mathrm{~d}$ & $1.970 \pm 0.225 \mathrm{~d}$ & $0.011 \pm 0.000 \mathrm{~b}$ & $2.039 \pm 0.015 \mathrm{e}$ \\
C. monogyna subsp. monogyna & $2.650 \pm 0.167 \mathrm{C}$ & $1.953 \pm 0.010 \mathrm{~g}$ & $0.780 \pm 0.016 \mathrm{~d}$ & $1.080 \pm 0.057 \mathrm{i}$ & $0.027 \pm 0.001 \mathrm{~b}$ & $1.721 \pm 0.024 \mathrm{f}$ \\
C. curvisepala & $2.335 \pm 0.036 \mathrm{~d}$ & $3.245 \pm 0.72 \mathrm{e}$ & $1.474 \pm 0.087 \mathrm{~b}$ & $1.580 \pm 0.054 \mathrm{e}$ & $0.013 \pm 0.001 \mathrm{~b}$ & $1.167 \pm 0.014 \mathrm{j}$ \\
C. szovitsii & $0.537 \pm 0.009 \mathrm{~g}$ & $3.378 \pm 0.078 \mathrm{e}$ & $1.094 \pm 0.085 \mathrm{C}$ & $1.556 \pm 0.113 \mathrm{ef}$ & $0.011 \pm 0.000 \mathrm{~b}$ & $1.472 \pm 0.055 \mathrm{~h}$ \\
Crataegus pentagyna & $1.741 \pm 0.042 \mathrm{e}$ & $5.641 \pm 0.170 \mathrm{~d}$ & $1.145 \pm 0.102 \mathrm{C}$ & $2.133 \pm 0.113 \mathrm{C}$ & $0.015 \pm 0.000 \mathrm{~b}$ & $2.542 \pm 0.042 \mathrm{~b}$ \\
C. aroni var. aroni & $1.470 \pm 0.021 \mathrm{f}$ & $10.696 \pm 0.055 \mathrm{c}$ & $0.735 \pm 0.025 \mathrm{~d}$ & $1.530 \pm 0.056 \mathrm{f}$ & $0.025 \pm 0.001 \mathrm{~b}$ & $2.088 \pm 0.028 \mathrm{~d}$ \\
\hline
\end{tabular}

*There were significant $(P<0.01)$ differences among the different letters in the same columns. 
Table 3 Sugars and vitamin C contents of examined hawthorn species (fresh weight basis)

\begin{tabular}{|c|c|c|c|c|}
\hline Species & Glucose $(\mathrm{g} / 100 \mathrm{~g})$ & Fructose $(\mathrm{g} / 100 \mathrm{~g})$ & Saccharose $(\mathrm{g} / 100 \mathrm{~g})$ & Vitamin C (mg/100 g) \\
\hline C. pontica & $7.131 \pm 0.102 h^{*}$ & $8.527 \pm 0.051 \mathrm{e}$ & $1.205 \pm 0.045 \mathrm{~cd}$ & $9.418 \pm 0.014 a$ \\
\hline C. atrosanguinea. & $9.907 \pm 0.003 d$ & $16.619 \pm 0.076 b$ & $1.305 \pm 0.145 b c$ & $2.805 \pm 0.126 \mathrm{~g}$ \\
\hline C. meyeri & $9.416 \pm 0.051$ ef & $9.591 \pm 0.118 \mathrm{e}$ & $1.395 \pm 0.074 \mathrm{abc}$ & $2.780 \pm 0.184 \mathrm{~g}$ \\
\hline C. pseudoheterophylla & $12.513 \pm 0.057 b$ & $16.861 \pm 0.100 b$ & $1.269 \pm 0.076 c$ & $3.738 \pm 0.242 \mathrm{e}$ \\
\hline C. orientalis var. orientalis & $11.821 \pm 0.143 c$ & $16.633 \pm 0.156 b$ & $1.517 \pm 0.050 \mathrm{ab}$ & $5.390 \pm 0.102 c$ \\
\hline C. monogyna subsp.azarella & $7.527 \pm 0.166 \mathrm{~g}$ & $11.386 \pm 0.119 c$ & $0.999 \pm 0.035$ de & $8.091 \pm 0.087 b$ \\
\hline C. monogyna subsp. monogyna & $13.893 \pm 0.021 \mathrm{a}$ & $18.378 \pm 0.202 \mathrm{a}$ & $0.970 \pm 0.005 e$ & $4.301 \pm 0.121 \mathrm{~d}$ \\
\hline C. curvisepala & $9.194 \pm 0.073 f$ & $11.536 \pm 0.064 c$ & $1.173 \pm 0.003$ cde & $4.182 \pm 0.006 d$ \\
\hline C. szovitsii & $6.672 \pm 0.193 i$ & $10.257 \pm 0.163 d$ & $0.979 \pm 0.025 \mathrm{de}$ & $3.260 \pm 0.016 f$ \\
\hline Crataegus pentagyna & $9.536 \pm 0.079 \mathrm{e}$ & $11.404 \pm 0.250 c$ & $1.564 \pm 0.105 a$ & $4.439 \pm 0.064 d$ \\
\hline C. aroni var. aroni & $7.074 \pm 0.072 h$ & $10.593 \pm 0.132 d$ & $0.954 \pm 0.008 \mathrm{e}$ & $1.555 \pm 0.091 \mathrm{~h}$ \\
\hline
\end{tabular}

*There were significant $(\mathrm{P}<0.01)$ differences among the different letters in the same columns.

contain saccharose. Glucose and fructose are the predominant sugar compounds in all fruits and vegetables. Saccharose and mannose may also exist in lower amounts. Recent studies on hawthorn have demonstrated that hawthorn berries are good for boosting heart health, regulating heart beat irregularities, alleviating spasms and lowering blood pressure in addition to their laxative, diuretic and antitumoural properties [13]. These beneficial health effects increased the awareness about the importance of this fruit in nutrition.

\section{Conclusions}

In the literature there are a limited number of studies on morphological and biochemical contents in hawthorn fruits. Particularly the study included a number of hawthorn species and hence this study is considered to be a valuable reference for forthcoming studies on morphological and biochemical characteristics of the species to find the most favorable one to introduce it into for bring them commercial production. The results suggested its high potential of health benefits. However, more detailed biological and pharmacological studies are needed for the demonstration and clarification of health benefits of hawthorn fruits.

\section{Methods}

\section{Plant materials}

Homogeneous fruits samples were collected at the harvest time of the determined C. szovitsii Pojark., C.pontica C. Koch., C. aroni var. aroni (L) Bosc.ex DC., C. atrosanguinea Pojark., C. meyeri Pojark., C. curvisepala Lindman, $C$. monogyna subsp. monogyna Joiq., C. pseudoheterophlla Pojark., C. orientalis var. orientalis Pallas ex Bieb., $C$. monogyna sulbsp.azarella Jocq., Crataegus pentagyna fruits grown in Erzincan province. Altitude of Erzincan is $1214 \mathrm{~m}$. Fruit samples were collected from towns (Otlukbeli, Kemaliye, Çayırlı, İliç) connected with Erzincan.
Erzincan has a temperate climate with annual average temperature of $10.7^{\circ} \mathrm{C}$. The average annual rainfall in the province is $344 \mathrm{~mm} / \mathrm{m}^{2}$.

\section{Morphological and biochemical characteristics of fruits}

Thirty matured hawthorne fruits were selected based on morphological characteristics for fruit analyses. Desirable morphological and biochemical characteristics such as fruit weight $(\mathrm{g})$, fruit length $(\mathrm{mm})$, fruit diameter $(\mathrm{mm})$, seed weight $(\mathrm{g})$, seed number, fruit stalk length $(\mathrm{mm})$, fruit stalk thickness $(\mathrm{mm})$, fruit juice $\mathrm{pH}$, soluble solid content (SSC,\%) and acidity (\%) were determined according to Cemeroglu [17]. Fruit samples from each species were maintained at $-20^{\circ} \mathrm{C}$ before organic acids, sugars and vitamin $C$ analysis.

\section{Extraction and determination of organic acids}

In the present study, chemicals with analytical purity were used. Organic acid standards (citric acid, tartaric acid, oxalic acid, malic acid, succinic acid and fumaric acid), sugar standards (glucose, fructose, and sucrose), and vitamin C standards (l-ascorbic acid) were obtained from SigmaAldrich (St. Louis, MO, USA). The other chemicals were obtained from Merck (Darmstadt, Germany).

For organic acid extraction, the method by Bevilacqua and Califano [18] was modified. About $200 \mathrm{~g}$ of samples was fragmented and $10 \mathrm{~g}$ from each sample was delivered to centrifuge tubes. The $10 \mathrm{ml}$ of $0.009 \mathrm{~N} \mathrm{H}_{2} \mathrm{SO}_{4}$ was added to the samples and the samples were homogenized with Heidolph Silent Crusher M, Germany. Then, the samples were mixed for an hour with a shaker (Heidolph Unimax 1010, Germany) and centrifuged at $14.000 \times \mathrm{rpm}$ for $15 \mathrm{~min}$. The supernatants were passed through coarse filter paper, then twice through a $0.45 \mathrm{~mm}$ membrane filter (Millipore Millex-HV Hydrophilic PVDF, Millipore, USA), and last in a SEPPAK C18 cartridge. The concentration of organic acids 
was determined by HPLC using an Aminex column (HPX-87H, $300 \mathrm{~mm} \times 7.8 \mathrm{~mm}$, Bio-Rad) fitted on an Agilent 1100 series HPLC G 1322 A, Germany) [18]. Organic acids were detected at 214 and $280 \mathrm{~nm}$ wavelengths. The mobile phase, $0.009 \mathrm{~N} \mathrm{H}_{2} \mathrm{SO}_{4}$ was passed through a $0.45 \mu \mathrm{m}$ filter membrane.

\section{Extraction and determination of sugars}

The samples were prepared according to the method described by Melgarejo et al. [19] with minor modifications. Briefly, the samples of $10 \mathrm{~g}$ fruit were centrifuged at $12.000 \mathrm{rpm}$ for $2 \mathrm{~min}$ at $4{ }^{\circ} \mathrm{C}$. Then the supernatant was filtrated with SEP-PAK C18 cartridges and transferred into a vial and used for analysis. Analysis of sugars was performed by HPLC (isocratic program) equipped with a $\mu$ bondapak- $\mathrm{NH}_{2}$ column and a refractive index (RI) detector using $85 \%$ acetonitrile as a mobile phase. The calculation of concentrations was based on standards prepared in the laboratory.

\section{Extraction and determination of ascorbic acid (vitamin C)} Ascorbic acid content was determined following the modified HPLC (isocratic program) (Agilent 1100 series HPLC G 1322 A, Germany) analytical procedure outlined by Cemeroglu [20]. The $10 \mathrm{~g}$ of sample was delivered to a $50 \mathrm{ml}$ volumetric flask including $10 \mathrm{ml} 6 \%(\mathrm{w} / \mathrm{v})$ metaphosphoric acid (Sigma, M6285, 33.5\%). The sample was then homogenized at $24.000 \mathrm{rpm}$ for $15 \mathrm{~s}$, and centrifuged at $14,000 \mathrm{rpm}$ for $10 \mathrm{~min}$ at $1^{\circ} \mathrm{C} .5 \mathrm{ml}$ of the supernatant was filtered through $0.45 \mu \mathrm{m}$ PTFE syringe filters (Phenomenex, UK) and placed in an amber colored vial (AIM, Screw vial, SV-15A). Quantification of ascorbic acid was made by an external standard method using an 1 -ascorbic acid standard (Sigma A5960). Samples were separated on a Luna C18 column $(250 \mathrm{~mm} \times 4.60 \mathrm{~mm}$, $5 \mu \mathrm{m}$ from Phenomenex) at $25^{\circ} \mathrm{C}$ by an HPLC. The mobile phase was $25 \mathrm{mM} \mathrm{KH}_{2} \mathrm{PO}_{4}$ (adjusted to $\mathrm{pH} 2.2$ with phosphoric acid) with a flow rate of $1 \mathrm{ml} / \mathrm{min}$. L-ascorbic acid was detected at $254 \mathrm{~nm}$.

\section{Statistical analysis}

Experimental data were evaluated using analysis of variance (ANOVA) and significant differences among the means of three replicates $(p<0.05)$ were determined by Duncan's multiple range tests, using the "SPSS 10.0 for Windows".

\section{Competing interests}

The author's declare that they have no competing interests.

\section{Author's contributions}

$M G, K O$ and TK made a significant contribution to experimental design, acquisition of data, analysis and drafting of the manuscript. SE, OK and AH have made a substantial contribution to interpretation of data, drafting and carefully revising the manuscript for intellectual content. All authors read and approved the final manuscript.

\section{Author details}

'Department of Agriculture Biotechnology, Yuzuncu YIl University, Agriculture Faculty, Van, Turkey. ${ }^{2}$ Department of Horticulture, Siirt University, Agriculture Faculty, Siirt, Turkey. ${ }^{3}$ Department of Horticulture, Ataturk University, Agriculture Faculty, Erzurum, Turkey. ${ }^{4}$ Department of Horticulture, Inonu University, Agriculture Faculty, Malatya, Turkey. ${ }^{5}$ Departement of Pomology, National School of Agriculture, Meknes, Morocco. ${ }^{6}$ Corvinus University of Budapest, Faculty of Horticultural Science, Budapest, Hungary.

Received: 6 April 2014 Accepted: 21 May 2014

Published: 30 May 2014

\section{References}

1. Tadic MV, Dobric S, Markovic MG, Dordjevic MS, Arsic Al: Anti-inflammatory, gastroprotective, free-radical-scavenging, and antimicrobial activities of hawthorn berries ethanol extract. J Agric Food Chem 2008, 56:7700-7709.

2. Ercisli S: A short review of the fruit germplasm resources of Turkey. Gen Res Crop Evol 2004, 51:419-435.

3. Guo TJ, Jiao PJ: Hawthorn (Crataegus) resources in China. HortSci 1995, 30:1132-1134

4. Yilmaz KU, Yanar M, Ercisli S, Sahiner H, Taskin T, Zengin Y: Genetic relationships among some hawthorn (Crataegus spp.) species and genotypes. Biochem Genetics 2010, 48:873-878.

5. Caliskan O, Kazim G, Serce S, Toplu C, Kamiloglu O, Sengul M, Ercisli S: Phytochemical characterization of several howthorn (Crataegus spp) species sampled from the Eastern Mediterranean region of Turkey. Pharmacognosy Maga 2012, 8:16-21.

6. Savran HS: Nar Suyunda Organik Ait Dağılımı (yüksek lisans tezi). Ankara: AÜ, Fen Bilimleri Enstitüsü; 1999.

7. Chang W, Dao J, Shao Z: Hawthorn: potential roles in cardiovascular disease. Amer J Chinese Med 2005, 33:1-10.

8. Quettier-Deleu C, Voiselle G, Fruchart JC, Duriez P, Teissier E, Bailleul F, Vasseur J, Trotin F: Hawthorn extracts inhibit LDL oxidation. Pharmazie 2003, 58:577-581.

9. Cui T, Nakamura K, Tian S, Kayahara S, Tian Y: Polyphenolic content and physiological activities of Chinese hawthorn extracts. Biosci Biotech Biochem 2006, 70:2948-2956.

10. Bernatoniene J, Masteikova R, Majiene D, Savickas A, Kevelaitis E, Bernatoniene R, Dvorackova K, Civinskiene G, Lekas R, Vitkevicius K, Peciura R: Free radicalscavenging activities of Crataegus monogyna extracts. Medicina (Kaunas) 2008, 44:706-712.

11. Liu P, Kallio H, Lu D, Zhou C, Ou S, Yang B: Acids, sugars, and sugar alcohols in Chinese hawthorn (Crataegus spp.) fruits. J Agric Food Chem 2010, 58:1012-1019.

12. Tanker N, Koyuncu M, Coskun M: Farmasotik Botanik. 78th edition. Ankara: Ankara Üniversitesi Eczaclık Fakültesi Yayınları; 1998:233.

13. Baytop T: Türkiye'de Bitkiler Ille Tedavi (Geçmişte ve Bugün). 3255th edition. Istanbul: Istanbul Üniversitesi, Eczacl lik Fak. Yayınlarl; 1984:520. 13. Karadeniz T, Kalkisim O: Edremit ve Gevaş ilçelerinde yetişen alıç tiplerinin meyve özellikleri ve ümitvar tiplerin seçimi. J Agric Yuzuncu Yil Univ 1996, 6: 27-33.

14. Zhao HC, Tian BF: China Fruit-Plant Monograph. In Hawthorn Flora. Beijing, China: Zhongguo Lin Ye Press; 1996:14-65.

15. Gao GY, Feng YX, Qin XQ: Analysis of the chemical constituents of hawthorn fruits and their quality evaluation. Yaoxue Xuebao 1995, 30:138-143.

16. Gundogdu M, Yilmaz H: Organic acid, phenolic profile and antioxidant capacities of pomegranate (Punica granatum L.) cultivars and selected genotypes. Sci Hortic 2012, 143:38-42.

17. Cemeroglu B: Meyve ve Sebze Issleme Endüstrisinde Temel Analiz Metodları. Ankara: Biltav Yayınları; 1992:381

18. Bevilacqua $A E$, Califano AN: Determination of organic acids in dairy products by high performance liquid chromatography. J Food Sci 1989, 54:1076-1079.

19. Melgarejo P, Salazar DM, Artes F: Organic acids and sugars composition of harvested pomegranate fruits. Eur Food Res Tech 2000, 211:185-190.

20. Cemeroglu B: Gıda Analizleri. GIda Tekn Der Yayı 2007, 34:168-171.

doi:10.1186/0717-6287-47-21

Cite this article as: Gundogdu et al:: Organic acids, sugars, vitamin C content and some pomological characteristics of eleven hawthorn species (Crataegus spp.) from Turkey. Biological Research 2014 47:21. 